\title{
The Keys of S. Peter at Liege and Maestricht
}

\section{E. W. Beck}

To cite this article: E. W. Beck (1890) The Keys of S. Peter at Liege and Maestricht, Archaeological Journal, 47:1, 334-342, DOI: 10.1080/00665983.1890.10852434

To link to this article: http://dx.doi.org/10.1080/00665983.1890.10852434

$$
\text { 曲 Published online: } 15 \text { Jul } 2014 .
$$

Submit your article to this journal $\widetilde{ }$

Q View related articles $₫$ 


\section{THE KEYS OF S. PETER AT LIEGE AND MAESTRICHT.।}

By E. W. BECK.

To rightly understand what these keys are we must go back to the earliest ages of Christendom, to the Martyrdom, in fact, of the Holy Apostles Peter and Paul, which it is needless to remind you took place in Rome on June 29th, A.D., 67. The bodies of these Apostles rest in the two Basilicas dedicated in their honour on the Vatican Hill and the Ostian Way respectively; their heads being placed together in the Cathedral of Rome, the Basilica of S. John Lateran omnium ecclesiarum urbis et orbis mater et caput. So great was the veneration of the Roman Christians for these sacred remains that for centuries the Popes themselves did not venture to disturb them. ${ }^{2}$ Something had to be done, however, to satisfy the craving of Catholics in other parts of the world, who from time to time asked the Popes to give them some relic of the two great Apostles. For example, early in the sixth century Justinian, nephew to the Emperor Justin I, and himself afterwards Emperor, made such a request to $\mathrm{S}$. Hormisdas $;{ }^{3}$ as in due course did the Empress Constantina to S. Gregory the Great. ${ }^{4}$ The custom arose of sending brandea, ${ }^{5}$ that is linen cloths which had rested on the bodies of the Saints; and perhaps some here present may remember a very beautiful mosaic altarpiece in the Vatican Basilica referring to this subject. Another custom was to send relics of the chains of the Apostles, and this is the one which directly concerns us.

The chain which the Prince of the Apostles wore in

${ }^{1}$ Read at the Monthly Meeting of the Institute, July 3, 1890 .

${ }^{2}$ Cf. Epp. S. Areg. M. iv., 30 (Migne's edition.)

${ }^{3}$ Epp. Et Decreta Hormisdoe Papce in Migne's Patrol. Lat., vol. 63, col. 475

4 Epp. S. Qreg. iv, 30.

Ibid. 
the Mamertine Prison was treasured among the most sacred relics of Christian Rome. Of the veneration paid to it we have evidence in the Acts of S. Alexander, who was martyred in the second century; acts which though probably not by a contemporary are yet of early date. To this chain was in time added one of those which the Apostle wore in Jerusalem when he lay bound by order of Herod the King. When this chain was brought to Rome is unknown, but it was certainly not later than the beginning of the sixth century; for, in the reign of Justinian, Arator, subdeacon of the Holy Roman Church, wrote a poem on the Acts of the Apostles, in which he mentioned that one of the Jerusalem chains was in Rome:-
His solidata fides, his est tibi, Roma, catenis
Perpetuata salus; barum circumdata nexu
Libera semper eris; quid enim non vincula præstent,
Quæ tetigit, qui cuncta potest absolvere? Cujus
Hæc invicta manu, vel religiosa triumpho
Moenia non uلlo penitus quatientur ab hoste
Claudit iter bellis, qui portam pandit in astris. ${ }^{1}$

It is commonly believed " that Eudocia, wife of Theodosius the younger, in 439 brought from Jerusalem the two chains ...... and having given one to a church in Constantinople sent the other to Rome to her daughter Eudoxia, who was married to Valentinian III."'2 But the evidence of this is not of a very satisfactory nature. Since the fifth century they have been kept in the church of S. Peter's Chains; more commonly called the Eudoxian Basilica after the Empress Eudoxia who built it. The chest which contains them has three locks. One of the keys is kept by the Pope; the second by the Cardinal Titular of the Church; and the third by the Abbot General of the Austin Canons of the Lateran congregation, to whom the Basilica belongs. They are exposed to public veneration on July 3rd and during the octave of the feast of S. Peter's Chains; which feast is kept in the West on August 1st, though in the East from early times January 16 th has been assigned to it.

1 Arator, de Actibus App. lib. i., vv. 1070 ss. (Migne's edition). Among the poems of Blessed Alcuin, O.S. B. (Migne's editiun) is one almost identical with the above; in fact the only differences are that the second line runs as follows, Simplicio nunc ipse dedit sacra jure tenere, and in the fifth we have manus for manu (Aluini opp., vol, ii., col. 770).

${ }^{2}$ Butler, Lives of the Saints, Aug. 1st. 
The chains of $\mathrm{S}$. Paul do not so much concern us, though, as relics of them were sometimes placed with those of the chains of S. Peter, it may be well to mention that they are preserved in the sacristy of the Basilica of $\mathrm{S}$. Paul-without-the-walls on the Ostian Way. They are exposed on January 25th and June 30th; but permission to see them may at all times be easily obtained from the Abbot of the Benedictine convent adjoining the Basilica.

The earliest written evidence we have of a gift of a relic of S. Peter's chains relates to that made by $\mathrm{S}$. Hormisdas to Justinian, at the same time that he refused him a part of the body. The practice of sending such a relic in a key must have been in vogue before the end of the sixth century; for S. Gregory the Great (the thirteenth centenary of whose ordination occurs on September 3rd of this year) mentions that one was sent back to Rome, to Pelagius II., by a pagan Lombard king named Autharith who had been struck with fear on account of the sudden and, as he believed, miraculous death of another Lombard chieftain who had wished to profane it." S. Gregory himself sent a small cross containing relics of the chains of one or both apostles to Eulogius Patriarch of Alexandria; ${ }^{2}$ and to the Patrician Dynamius. ${ }^{3}$ The same Pope also sent a number of keys to various dignitaries; but to pass over for the present these and other instances in which the relic was enclosed in a key, we find that early in the eighth century Pope Constantine sent a relic of the chains to Evaldus, Archbishop of Vienne, though there is no evidence to show what form the reliquary took. And then to come to more modern times a few instances can be given on the authority of Monsacrati, an Austin Canon, whose classical work re catenis Sancti Petri was dedicated to the erudite Benedict XIV. ${ }^{4}$ Leo X. it seems gave a link of one of the chains to the Cardinal Albert of Magdeburg, Archbishop-Elector of Maintz; Paul III. gave another to Cardinal Gambara; in the last century Cardinal Albano, presumably the Titular of the Church, gave one to Frederic, Prince Royal of Poland; and Benedict

1 Epp. vii, 26.

2 Epp. xiii, 42.

3 Ibid. iij, 33.

D. Michaelis Angeli Monsacrati, abbatis ex ordine canonicorum regularium S. Salvatoris de Catenis S. Petri dissertatio ad Benedictum XIV, P.O.M.

Romæ, MDCCL. 
XIV. sent some relics to Bologna, of which he had been Archbishop when Cardinal Lambertini. At the present day it is the custom for the custodian of the relics to collect some of the rust when the chains are exposed, and to scatter it on linen which is given away with a proper authentication from the Abbot.

To return to the keys. From his epistles we learn that S. Gregory the Great sent one to each of the following: Anastasius, Patriarch of Antioch :' Theodore, a physician of Constantinople $;^{2}$ a nobleman named Andrew ; ${ }^{3}$ a noble lady named Theoctista, ${ }^{4}$ who was charged with the education of the sons of the Emperor Maurice; to John, ${ }^{5}$ patrician, quæstor and ex-consul ; to Leontius, ${ }^{6}$ also an exconsul; to a certain Gaulish noble, Asclepiodotus ${ }^{7}$ by name; and to Savinella. ${ }^{8}$ To Rechared, ${ }^{9}$ King of the Visigoths, he sent two, of which one, it has been suggested, was meant for S. Leander, to whom he sent the pallium by the same messenger; though possibly the keys belonged to two different classes, as one was said by S. Gregory to contain a relic of the chain, whilst no such statement was made of the other. To Columbus, ${ }^{10}$ bishop of Numidia, and to Childebert, ${ }^{11}$ king of the Franks, he sent more than one, but how many is not known. It may be noted that relics of the Apostles-almost certainly either brandea or keys-were sent to the last-named by Pelagius II. ${ }^{22}$

S. Vitalian, who ascended the Pontifical Throne in 657, sent one, containing relics of both chains, to his spiritual daughter, the wife of the Northumbrian King Oswy, over whose piety, he said, the whole Apostolic See rejoiced. The letter written on the occasion has been preserved for us by the Venerable Bede. ${ }^{13}$

About a hundred years after this S. Gregory III. sent two

${ }_{1}$ Epp. i, 26.

2 Ibid. vii, 28.

${ }^{3}$ Ibid. i, 30 .

4 Ibid. vii, 26.

5 Tbid, i, 31.

6 Ibid. viij, 35.

7 Ibid. xi, 14.

Ibid. xii, 7 .

- Ibid ix, 122.

so Ibid. iii, 48 .

11 Ibid. vi, 6 .

VOL, XLVII,
12 Migne, Patrol. Lat. lxix, Ep. 9.

13 ... Nam et conjugi vestre, nostre spiritali filiæ, direximus per præfatos gerulos crucem clavem auream habentem de sacratissimis vinculis beatorum apos. tolorum Petri et Pauli: de cujus pio studio cognoscentes, tantum cuncta sedes apostolica una nobiscum latatur quan. tum ejus pia opera coram Deo fragrant et vernant. . . . Bedoc Hist. Eccles. iij, 29. 
of these keys to Charles Martel : $:^{1}$ half a century later S. Leo III. sent one to B. Charles the Great, ${ }^{2}$ four years before he crowned him Emperor of the West, on the memorable Christmas-day of the year 800 . The last instance which can be cited brings us to the year 1079, in which S. Gregory VII., the illustrious Hildebrand, sent a golden key to Alphonsus $\nabla .^{3}$ of Castile, saying in the accompanying letter that in so doing he followed the custom of the Saints. ${ }^{4}$

In several of the Epistles of S. Gregory we find the phrase "we send you a key from the most holy body of S. Peter." A similar phrase occurs in the ritual which is followed to the present day, when the pallium is conferred on those archbishops and bishops that have the right to receive it. On such occasions the officiant says, "We deliver to you the pallium taken from the body of Blessed Peter," and it is hardly necessary to say that the pallia are kept in the confession or crypt under the high altar of $\mathrm{S}$. Peter's, which contains part of the body of the Holy Apostle. From this we may infer that the keys sent by the Popes were either kept in the confession or placed on the shrine of S. Peter before being given away; and to this circumstance we may probably trace the legends of various Saints having received a key from S. Peter. Another point to be noticed is that S. Gregory points out that these keys, which in fact were reliquaries, should be worn hanging from the neck. ${ }^{6}$

As to the relic of the chain. In the key at Liege this is enclosed in the hollow of the handle; it can be seen, and is in no way fixed. This must have been a common mode of dealing with the relic, and is indicated by the phraseology of several of S. Gregory's epistles. Sometimes, however, in place of sending detached portions of the chain, some filings of it were mixed with the molten metal when the key was being cast.

There is another kind of key which should be mentioned

1 Epp. S. Gregorii III. apud Migne Patrol. xcviii, No. 22; and Fredegarii Scholastici Chronicon, apud Migne Patrol. 'xxi, No. 680 .

2 Vide Migne Put. Lat., vol. 98, col. 495 , xiii, ad. fin. editio?
${ }^{4}$ I have read somewhere, but cannot now put $m y$ hand on the reference that the same Pontiff sent a key to the King of Denmark.

${ }^{5}$ Epp. i, 30, 31 ; vii, 26,28 ; ix, 122 ; xi, 14 ; xii, 7 .

${ }^{6} E_{\text {pp. }} \mathrm{i}, 30,31$; iij, 33 ; vi, 6 ; xi, 14 ; $\mathrm{xij}, 7$. 


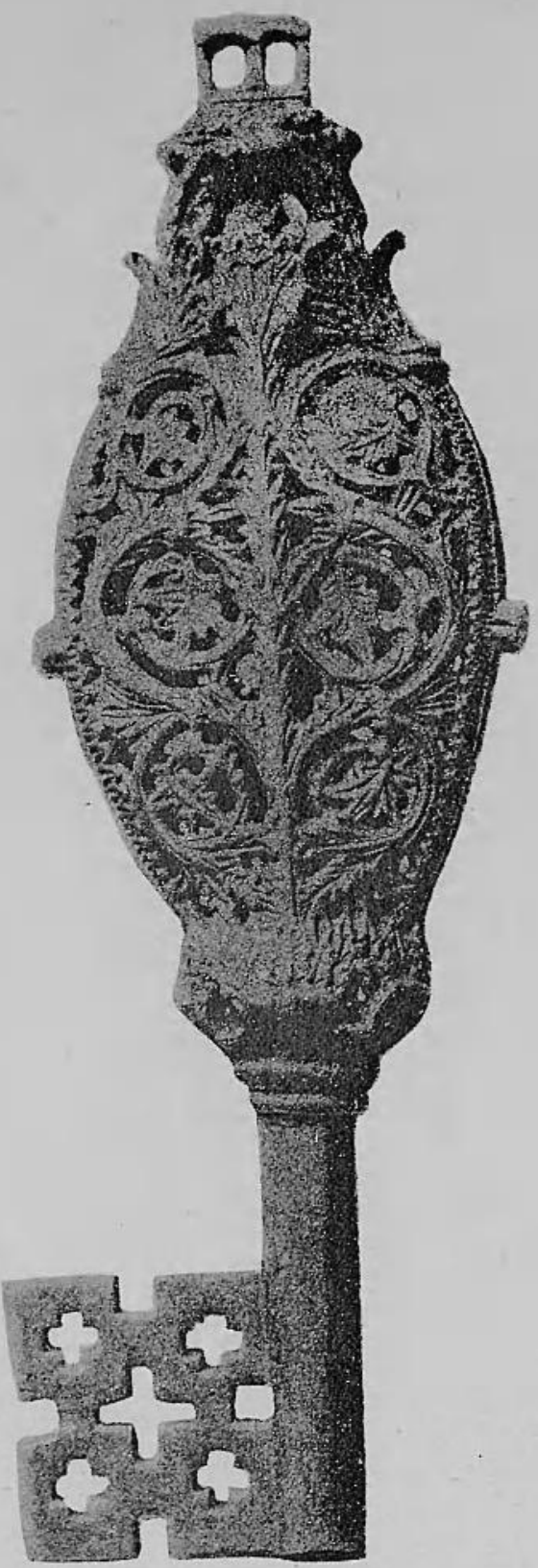

KEY OF ST, PETER AT MAESTRIOHT 
as possibly the one at Maestricht is a specimen of it. S. Gregory of Tours, writing in the sixth century, says that the keys used for locking the doors of the confession were regarded as relics, and that pious people would often send golden keys to Rome in exchange for them. ${ }^{1}$ Possibly too the key sent by S. Gregory the Great to the exConsul Leontius belonged to this class for he speaks of it as a key of the confession of S. Peter, mentioning, however, at the same time that it contained a relic of the chains.

All the keys which have been described are spoken of as the "keys of S. Peter," a phrase which occurs three times in S. Gregory; and not unfrequently as "keys of the confession of S. Peter," a term which, as has just been mentioned, is found once in the writings of that Pope. The latter term may be due to one of two things. Either it was generally applied because some of the keys were actually used for locking the confession; or it was given because those which were not keys of the door had been kept in the confession or at least placed in it for a time.

Of these keys two only are now known to exist in Western Christendom; of the East the various writers on the subject appear to have no information. The two still in existence are those which furnish the title of this paper; and of them the one at Maestricht, the capital of Dutch Limburg, is in the opinion of experts the older by some four centuries.

The Maestricht key is kept in the rich treasury of the old collegiate church of S. Servais, formerly the cathedral of the Saint, who, in the opinion of the Bollandists, received the key from Pope S. Damasus. Mr. W. H. James Weale, appointed Keeper of the National Art Library at Kensington since this paper was read, in the interesting and exhaustive article which he wrote on these keys for Le Beffroi, ${ }^{2}$ endorses this opinion; and adds that most probably it was about the year 376 on the occasion of a pilgrimage made by the Saint to the tomb

1 Multi emin et claves aureas ad reserandos cancellos beati sepulchri faciunt qui ferentes pro benedictione priores accipiunt quibus infirmati tribulatorum medeantur. Omnia enim fides integra prostat, S. Greg. Turon. De gloria
Maryy'um xxviij, Migne's edition, $\mathbf{S}$. Gregory the Great likewise speaks of miracles in connection with the keys containing the relic. [Epp. i, 2 $7,30,31$; vij, 26 ; and xiii, 42.]

${ }_{2}^{2}$ Vol. ij, Bruges, 1864. 
of S. Peter. The earliest reference we have to it is in the acts of the translation of S. Servais, which belong to the end of the 9 th century. ${ }^{\mathrm{T}}$ It is said in these acts that when the relics were translated by $\mathrm{S}$. Hubert at the beginning of the eighth century the key was found in the coffin to the left of the body. The "Key of S. Servais," as it is generally called, was sung of in the twelfth century by the Limburg poet, Henry van Veldeken as "the honour of the whole country;" nor were its praises confined to the secular muse for they were found in the hymn for Lauds in the Breviary formerly used by the Chapter, and in two proses of the old Missal. It became the emblem of the Saint whose oldest image, belonging to the twelfth century, bears it in the left hand; and it is found in the arms of the collegiate church dedicated in his honour. It appears, too, on money struck at Maestricht in the twelfth century by the Prince Bishop of Liege; and on imperial money minted there at a much earlier date. I am indebted to Mr. Weale for the knowledge of an early sixteenth century instance of such a representation of the Saint. It is found on the cover of one of the MSS. in the Six collection at Amsterdam; of which there is a rubbing in the magnificent collection of rubbings of bookbinding made by $\mathrm{Mr}$. Weale and acquired by the National Art Library. ${ }^{2}$ It will be interesting in this connection to recall a fact which $\mathrm{Mr}$. Bunnell Lewis noted in the appendix to his paper on the "Antiquities of Treves and Metz," published in the Journal, and to which he has very kindly called my attention; on some coins of 'Treves, to which, by the way, Maestricht was for a time subject, there is a hand holding two keys in allusion to S. Peter, the patron of the town, some of the letters

1 See Antiquiles Sacrés conservees dans les anciennes collegiales de SS. Servais et de Notre Dame a daestricht. Bock et Willemsen. Naestricht, 1873. I have to express my indebtedness to this work, as well as to that of Monsacrati and to $\mathbf{M r}$ Weale.

${ }^{2}$ In the "Catalogue of Bindings and Rubbings of Bindings in the National Art Library," by MIr. Weale, now in the press, it is thus described :- "Beneath a cusped arch supported by two brackets is a full length figure of $\mathrm{S}$. Servatius, bishop of Tongres and patron of the city of Maes- tricht, vested in alb cope and mitre, holding in his left hand the key of the Con. fession of S. Peter, still preserved in the cathedral of Maestricht, and in his right a pastoral staff, the point of which is piercing the throat of a dragon, on the prostrate body of which the Saint is standing, on each side an angel; above and around stars. A plain border with quatrefoils at the angles bears the legend [in black letter]: Seruatius seruavit | fidem seruauit plebem Domini I seruando et orando | meruit quod credidit alleluia. 


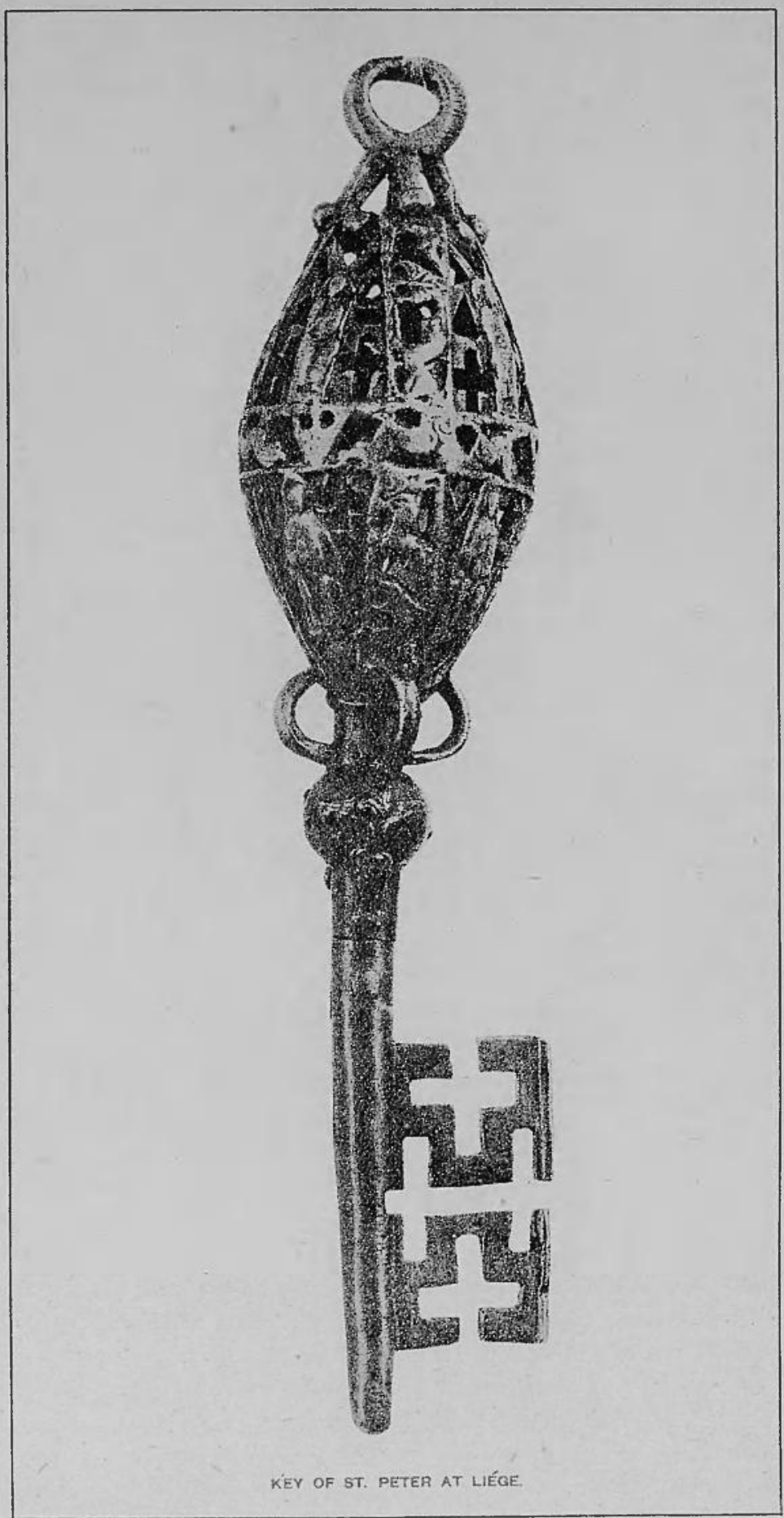


in the Apostle's name being arranged to form the wards of the keys.

The material of this key is said by the editors of the Antiquites to be a mixture of gold and silver of the kind anciently known as electrum, but $\mathrm{Mr}$. Weale says that it seems to be a mixture of silver and copper. The key was probably gilt originally, for there are remains of gilding in the parts less exposed to friction. The handle is oval ; divided into four compartments ; covered with ornaments of foliage. It is open work, but contains no relic, Possibly it is one of those in which the filings were mixed with the metal. The barrel of the key is octagon in form; the key-bit cruciform and pierced by five small crosses. Experts who have examined the key of $\mathrm{S}$. Servais have no hesitation in placing it among the works of the fourth century. It will be sufficient to note the names of Dr. Bock of Aix-la-Chapelle, and Mr. Weale; the last-named of whom is probably second to none in his knowledge of gothic art-a point of importance, for did the key belong to the XII or XIV century as has been suggested, he could hardly be deceived. As a matter of fact the material of which it is composed was not used by the artificers of the gothic period. Its dimensions are as follows:-Total length, about fifteen inches; length of hardle, about six inches; breadth of handle, about three and a half inches; breadth of key-bit nearly two inches.

The other key is at Liege, and is generally known as the "Key of S. Hubert," to whom a very constant tradition affirms that it belonged. This saint transferred his See from Maestricht to Liege early in the eighth century, and it is certainly a curious coincidence that the only keys of this class now known to exist should have belonged to bishops of the same diocese; and that they should now be preserved in the two towns, only fifteen miles apart, which at different times have been honoured with the episcopal chair, though now, indeed; they are not only in different dioceses but different countries.

The key of S. Hubert was originally kept in the church of S. Peter in which the Saint was buried; and very possibly it was removed from the coffin when his relics were translated early in the ninth century. It is now 
one of the treasures of the Church of the Holy Cross, and there can be no doubt of its authenticity in so far that it certainly is one of the "Keys of S. Peter." Its shape is very similar to that of the key of S. Servais, but the character of the ornamentation is very different. It is about fourteen and a half inches long, and the diameter of the handle is rather more than three inches. The handle only is ancient. The whole of the lower part, including the crucifix, cannot apparently be placed earlier than the second half of the twelfth century; it is believed that the original of this part perished in 1183 in the fire which destroyed the churches of S. Lambert and S. Peter. The handle is divided into eight triangular spaces by four bands running its whole length, each band about threequarters of an inch broad; another of the same breadth passing round the middle. The upper four spaces show $\mathrm{S}$. Peter holding a book, whilst in the lower four is represented the Majestas Domini, that is, our Lord sitting on the heavens holding the book of life in His left hand, whilst His right is raised in blessing. (On the band is a tree between two animals. There are triangular and cruciform openings through which the relic of the chain, about half an inch long, can be seen. The workmanship is inferior to that of the Maestricht key, a circumstance which has been explained by the low state into which art fell after the inroads of the barbarians, and from which it did not recover till long after the eighth century.

Mr. Weale mentions in the Le Beffroi that a key is mentioned in the inventory, made in 1523 , of the treasury of the Cathedral of Laon, which from the description he thinks may have been a key of S. Peter; but neither he nor the editors of the Antiquités Sacrees could say if it had escaped the hands of the revolutionists. The Bollandists mention another key which for long was preserved in a Corsican church, though at the time of publication of the June volume of the Acta Sanctorum it no longer existed. We have reason to be grateful to the churches of Liege and Maestricht for having preserved their keys with such jealous care; but for them, unless indeed the Laon key should still be in existence, all trace of these interesting relics of the middle ages would have perished as completely as the custom of sending the keys itself. 